\title{
Concentration and risk assessment of toxic metals in indoor dust in selected schools in Southeast, Nigeria
}

\author{
Kenechukwu E. Ugwu ${ }^{1,2}$ - Anthony C. Ofomatah ${ }^{1,2}$
}

Received: 26 August 2020 / Accepted: 28 December 2020 / Published online: 8 January 2021

(c) The Author(s) 2021 OPEN

\begin{abstract}
The health risk of students' exposure to some potentially toxic metals in classroom dusts in Southeast, Nigeria was assessed. Dust particles were collected from classrooms in some public high schools and digested with aqua regia before analysis for selected metals by atomic absorption spectrophotometry. The geoaccumulation index, contamination factor and the pollution load index were assessed from the metal concentrations of the dust. Hazard quotient and cancer risk index were used to estimate the potential health risk of students' exposure to the metals in the dust. The metal concentrations $(\mathrm{mg} / \mathrm{kg})$ were in the ranges of $1.57-175.38(\mathrm{Cr}) ; 0.93-463.28(\mathrm{Cu}) ; 31.94 .76-6623.41(\mathrm{Fe}) ; 4.96-143.98(\mathrm{Ni})$; 2.64-375.27 ( $\mathrm{Zn})$; and 2.35-53.96 (Pb).The geo-accumulation index values showed that all the dust samples were polluted with $\mathrm{Fe}$ and $\mathrm{Cr}$; and unpolluted with other metals with few exemptions. The contamination factor values showed that all the schools but one had a low contamination status due to $\mathrm{Ni}$ and $\mathrm{Cu}$. There was moderate contamination by $\mathrm{Pb}$ at all the schools but two. All the schools had high contamination of $\mathrm{Cr}$ and Fe. The pollution load index indicated that the quality of all the classrooms was deteriorated. The calculated values of hazard quotient indicated that ingestion of dust at most of the classrooms would have no significant risk of non-carcinogenic effects on the health of the students. Dermal contact with the dust at all the classrooms would expose students to adverse effects of Fe. There will be adverse effect due to $\mathrm{Pb}$ for dermal contact with dust at most of the schools. Ingestion of dust particles at classrooms in all the schools would have carcinogenic effect due to $\mathrm{Ni}$. Correlation analysis indicated that the sources of the metals varied. This study provided baseline data for relevant bodies to use in monitoring and controlling pollution so as to protect students from toxic metals.
\end{abstract}

Keywords Dust $\cdot$ Classrooms $\cdot$ Toxic metals $\cdot$ Health risk

\section{Introduction}

Dusts are airborne or settled small, dry, solid particles. They are generated naturally in sandstorms, volcanoes, wind, or from anthropogenic activities including bagging, demolition, crushing, conveying, grinding, shoveling, screening, sweeping and piling [1].

Dust particles released into the air will slowly settle due to the earth's gravitational force [2]. The sizes of dust particles vary; some may be less than $1 \mu \mathrm{m}$ and up to about
$100 \mu \mathrm{m}$ in diameter. Dust particles can be found indoors and outdoors. The airborne dust particles may be inhaled or may settle on human skin on contact. Dust particles may be dissolved by sweat and eventually enter the bloodstream through the skin pores. Human beings and animals may ingest dusty materials into their mouth or drink water with dust contamination. Human exposure to dust that occurs through oral intake, inhalation, and skin contact is of environmental concern because of the toxic constituents of the dust [3-5].

Kenechukwu E. Ugwu, kenechukwu.ugwu@unn.edu.ng| 'Department of Pure and Industrial Chemistry, University of Nigeria, Nsukka, Nigeria. ${ }^{2}$ National Center for Energy Research and Development, University of Nigeria, Nsukka, Nigeria. 
Different types of dust are generated from environmental processes due to their different sources. Therefore, the chemical constituents of dust particles vary. Among the chemical components of dust are metals. Human exposure to high levels of some metals leads to adverse health effects [6].

Reports of several researches on the concentrations of metals in dusts present in some environmental compartments indicate the extent of interests on this subject across the continents. Huang et al. investigated the amount of selected metals in indoor and outdoor dust particles found in cities of Guangzhou for contamination and risk assessment [7]. Taiwo et al. assessed road dust in Abeokuta, Nigeria, while Zheng et al. and Al-Khashman investigated the levels of heavy metals in the streets of Huludao, China and Amman, Jordan, respectively [8-10]. The results showed different levels of heavy metals in the areas. Nkansah et al. worked on the levels of metal in school classrooms at Kumasi, Ghana, where it was observed that geographical variation correlated with heavy metal load. Health risk assessment from this study showed that exposure through ingestion was more than exposure through dermal contact [11]. Popoola et al. [12] studied heavy metal concentrations in primary schools in Lagos, Nigeria, and revealed that the amount of the metals detected in classroom dust were lower than the levels observed in street dust of some other cities in the world.

Iniaghe et al. studied heavy metals indoor dust of primary schools in Delta State, Nigeria and opined that location of the schools as well as opened windows for ventilation could be possible routes for heavy metals contamination of classroom dust [13].

In many tropical and developing countries like Nigeria, dust particles are usually seen on most surfaces due to several uncontrolled human activities and natural factors. It is worrisome to notice the amount of settled indoor dusts at some public high school classrooms in Southeast Nigeria. It is common to see dust particles on various surfaces in the classrooms such as the windows, floors, tables, benches, chairs, walls, ceilings, books and shelves. Some of the buildings are dilapidated, lacking proper doors and windows to limit entry of door dust particles into the classrooms. In some schools, the windows and doors are always open without inhibition to entry of dust particles into the classrooms. Wind effect disperses particles from outdoors to indoor where these particles settle as dust. The dust may become resuspended thereby polluting the environment. Most classrooms also lack ceiling boards and are not painted, while in the few painted ones, the paints are peeling off. From literature, there are no prior studies of the pollution indices based on the levels of metals in public high classroom dusts in SE Nigeria. Also, the risk associated with major pathways of students' exposure to dust in the region has not been investigated. There is a possibility that health implications of exposure to metals in classroom dust may have been ignored or underestimated. There is no policy to regulate or control activities that may affect dust generation and dispersal in the schools. The World Health Organization (WHO) listed various health effects that may result from exposure to dust which included allergic responses, cancer, infection, inflammatory lung injuries, irritation, pneumoconioses and systemic poisoning [14].

Therefore, the aims of this study were: (1) to determine levels of toxic metals ( $\mathrm{Zn}, \mathrm{Pb}, \mathrm{Ni}, \mathrm{Fe}, \mathrm{Cu}$, and $\mathrm{Cr}$ ) in some $\mathrm{SE}$ Nigeria classrooms' dust; (2) to assess the pollution indices (geoaccumulation index (Igeo), contamination factors (CF) and pollution load index (PLI)) of the dust in the classrooms due to metals contamination, and (3) to assess the possible adverse health effects as a result of students exposure to the metals from ingestion, or dermal contact with the dust particles in their classrooms.

\section{Materials and methods}

\subsection{Sample collection and sampling sites}

Dust particles were collected from 72 sampling points in classrooms at selected public high schools in Enugu and Ebonyi States in Southeast, Nigeria. The map of the study area is presented in Fig. 1. The schools were chosen based on the student population, willingness of the schools to allow access and consideration of policies from separate state authorities.

Schools A, B, C and D are in rural areas and surrounded by farmlands where different crops were planted. The volume of vehicular movement around the schools was low. There was no industry with associated activities around the schools. Schools A and B are under a separate state environmental management authority from the other schools. Schools E, F, G and $\mathrm{H}$ are in urban environments where the volume of traffic due to vehicles was high. Lots of commercial activities with some industrial output were observed.

The samples were collected between August, 2019, and February, 2020, at three points in each classroom and nine classrooms from each school. At every sampling point, different hand gloves were worn and hard plastic brushes were used to gently sweep dust from the bookshelves, cemented floors, and tables in the classrooms into plastic bags. Samples were collected from the visible areas in the classrooms with easy accessibility and where students can easily have contact with dust. 


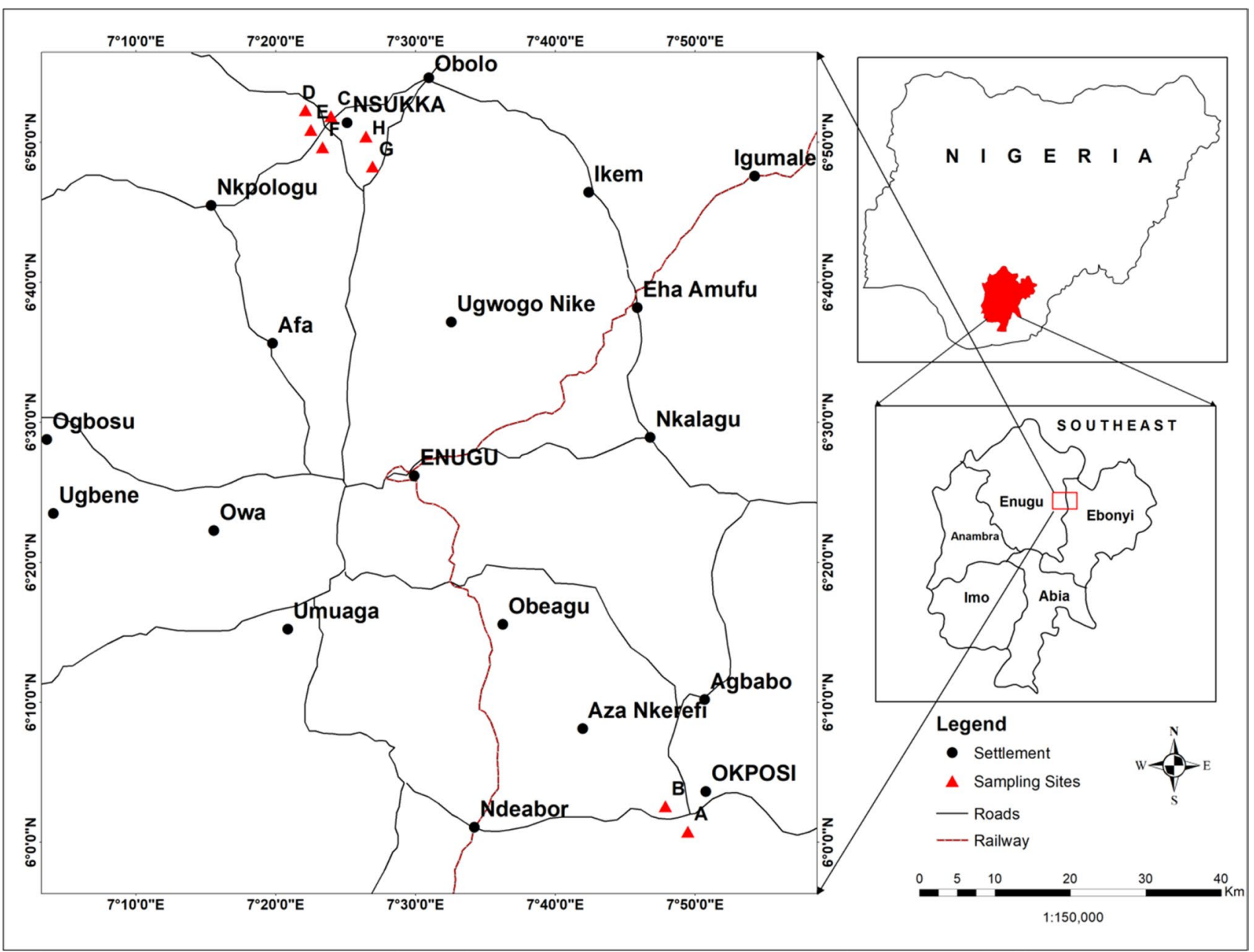

Fig. 1 Map of South East Nigeria showing the sampling locations

Dust particles collected from each classroom were mixed together as a composite sample which was then placed in sealed bags for each classroom.

\subsection{Sample preparation and analysis}

The dust samples in different labeled bags were put in a solar dryer at the National Center for Energy Research, University of Nigeria, Nsukka. After four days, the samples were screened with a standard test sieve (Rupson Industries, India) to remove pebbles and other objects larger than $100 \mu \mathrm{m}$ which were collected with the dust particles. The samples (about $5 \mathrm{~g}$ from each classroom) were stored for laboratory analysis.

About $1.0 \mathrm{~g}$ of the consolidated dust particles from each classroom was digested separately in a beaker using aqua regia $\left(3: 1 \mathrm{HCl}\right.$ and $\left.\mathrm{HNO}_{3}\right)$. This was done by adding $30 \mathrm{~mL}$ of the aqua regia to each of the samples in the $250 \mathrm{~mL}$ beaker. They were covered and heated on a hot plate, in a fume cupboard for $2.5 \mathrm{~h}$ at $120^{\circ} \mathrm{C}$. The digested mixture was then left to cool before it was filtered into a $50 \mathrm{~mL}$ volumetric flask, where it was made up to the mark with deionized water. Samples from each sampling point were digested in triplicates. Blanks were prepared and digested using the same procedure applied to the sample solutions.

After digestion, the concentrations of $\mathrm{Zn}, \mathrm{Ni}, \mathrm{Pb}, \mathrm{Fe}, \mathrm{Cu}$ and $\mathrm{Cr}$ in the digested samples and blanks were determined using an atomic absorption spectrophotometer (Model AA-7000, Shimadzu Corporation, Japan) which was connected to an air-acetylene flame burner. The equipment was calibrated with standard solutions of the metals to be determined.

\subsection{Quality control}

The analytical procedures were subjected to quality control check in the following ways: (1) Recovery experiments, in which mixed standard solution was spiked into 
the samples. A measured volume of the mixed standard solution was added to a dust sample. The spiked sample was digested and the concentrations of the metals in the spiked sample solutions were determined using the AAS. The percent recovery was calculated as

$\%$ Recovery $=\frac{\text { Css }- \text { Cus }}{\text { Cso }} \times 100$

where Css = concentration of the metal in the spiked sample, Cus = concentration of the metal in the unspiked sample, $\mathrm{Cso}=$ concentration of the metal in the spiked solution, (2) Triplicate digestions and analysis of the samples collected from each sampling point, (3) Use of metal concentrations in the blanks for corrections due to reagents, glassware and other materials, (4) The limit of detection (LOD) and the limit of quantitation (LOQ) for each element were determined. The determination was done to ascertain the working performance of the instrument, following a standard method [15]. The LOD and the LOQ were established from the calibration curves obtained when the standard solutions of each of the target metals were analysed in the instrument. The LOD was determined from the signal to noise ratio of 3 and the LOQ was based on the signal to noise ratio of 10 .

The results for the recovery experiments ranged between 80 and $98 \%$ for chromium, $84-97 \%$ for copper, $97-99 \%$ for iron, $86-97 \%$ for nickel, $92-99 \%$ for zinc, and $87-98 \%$ for lead.

The LoD values $(\mathrm{mg} / \mathrm{kg})$ for the metals were 0.00001 (Cr), $0.00001(\mathrm{Fe}), 0.00001(\mathrm{Cu}), 0.00001(\mathrm{Ni}), 0.0001(\mathrm{~Pb})$ and $0.00001(\mathrm{Zn})$. The LoQ values $(\mathrm{mg} / \mathrm{kg})$ were 0.0001 (Cu), $0.0001(\mathrm{Cr}), 0.0001(\mathrm{Zn}), 0.0001(\mathrm{Ni}), 0.0001(\mathrm{Fe})$ and $0.001(\mathrm{~Pb})$.

\subsection{Pollution indices of the potential toxic metals in dust}

In assessing the levels of contamination due to metals in the classroom dusts, the following pollution indices were investigated: (a) the geo-accumulation index, Igeo (b) the contamination factor, also known as the single factor pollution index (PI) and (c) the pollution load index.

The geo-accumulation index values were assessed using the Muller's expression [16] as given in Eq. 2:
The contamination factors, which interpret the values on the range of $<1$ to $>6$ were calculated using Eq. 3 by Forstner and Wittmann [18].

$\mathrm{CF}=\mathrm{C}_{\mathrm{s}} / \mathrm{C}_{\mathrm{b}}$

where $\mathrm{Cs}=$ concentration of the metal in the dust; $\mathrm{Cb}=$ concentration of the metal in the background sample [17]

The pollution load index was calculated from the contamination factor of each metal by using Eq. $4[19,20]$.

$\mathrm{PLI}=(\mathrm{CF} 1 \times \mathrm{CF} 2 \times \mathrm{CF} 3 \ldots \mathrm{CFn})^{1 / \mathrm{n}}$

where $\mathrm{n}$ is the number of metals assessed; and CF is the contamination factor of each toxic metal in the dust particles.

\subsection{Assessment of risk of exposure to some metals in classroom dust samples}

According to Luo et al. health risk assessment is the characterization of possible adverse health effects when humans are exposed to contaminants [21].

The non-cancer risk assessment of exposure to the heavy metals in the classroom dust particles was estimated from the values of the Hazard Quotient (HQ).

The cancer effects of students' exposure to some metals in their classroom dusts were assessed from the calculation of the carcinogenic risk index (CR).

Hazard Quotient is calculated from the ratio of the average daily dose (ADD) of the metal taken by a person to the reference dose $(\mathrm{RfD})$. It gives an indication of the average daily exposure that is safe to human population [22].

$H Q=\frac{A D D}{\operatorname{RfD}}$

This study used recommended RfD for the metals are presented in Table 1.

The major ways of students' exposure to toxic metals in dusts in their classroom are through oral intake or ingestion; inhalation; and by dermal contact with the dust particles.

Equation (6) [5] was used to calculate the $\mathrm{ADD}_{\text {ing-nc }}(\mathrm{mg} /$ $\mathrm{kg} /$ day) for non-cancer metals when dust particles in the classrooms are ingested:

Geoaccumulation index $=\log _{2}\left(\frac{\text { Concentration of the toxic metal in the dust particles }}{1.5 \times \text { Concentration of the toxic metal in the background sample }}\right)$

The crustal abundance values of the metals: $\mathrm{Cu}=45$, $\mathrm{Fe}=4.7, \mathrm{Ni}=68, \mathrm{Zn}=95, \mathrm{Cr}=90$, and $\mathrm{Pb}=20$ were adopted as their background concentrations [17], while the background constant for lithogenic correction is 1.5.

$$
A D D_{\text {ing-nc }}=\frac{C \times \operatorname{lgR} \times E D \times E F}{B W \times A T} \times 10^{-6}
$$


Table 1 RfD and Slope factor of some metals

\begin{tabular}{lllll}
\hline & $\begin{array}{l}\mathrm{RfD}_{\text {ing }} \\
\left(\mathrm{mg} \mathrm{kg}^{-1} \mathrm{day}^{-1}\right)\end{array}$ & $\begin{array}{l}\mathrm{RfD}_{\text {inh }} \\
\left(\mathrm{mg} \mathrm{kg}^{-1} \mathrm{day}^{-1}\right)\end{array}$ & $\begin{array}{l}\mathrm{RfD}_{\text {der }} \\
\left(\mathrm{mg} \mathrm{kg}^{-1} \mathrm{day}^{-1}\right)\end{array}$ & $\begin{array}{l}\mathrm{SF}_{\text {ing }} \\
\left(\mathrm{mgday}^{-1} \mathrm{mg}^{-1}\right)\end{array}$ \\
\hline $\mathrm{Cr}$ & $3.00 \times 10^{-3}[23]$ & $2.86 \times 10^{-5}[8]$ & $6.00 \times 10^{-5}[5]$ & $5.00 \times 10^{-1}[24]$ \\
$\mathrm{Cu}$ & $4.00 \times 10^{-2}[23]$ & $4.02 \times 10^{-2}[8]$ & $1.20 \times 10^{-2}[5]$ & \\
$\mathrm{Fe}$ & $7.00 \times 10^{-1}[23]$ & $3.00 \times 10^{-1}[8]$ & $6.00 \times 10^{-2}[8]$ & \\
$\mathrm{Ni}$ & $2.00 \times 10^{-2}[23]$ & $2.06 \times 10^{-2}[8]$ & $5.40 \times 10^{-3}[5]$ & $0.91[25]$ \\
$\mathrm{Zn}$ & $3.00 \times 10^{-1}[23]$ & $3.00 \times 10^{-1}[8]$ & $6.00 \times 10^{-2}[8]$ & \\
$\mathrm{Pb}$ & $3.50 \times 10^{-3}[23]$ & $3.52 \times 10^{-3}[8]$ & $5.25 \times 10^{-4}[8]$ & $0.0085[25]$ \\
\hline
\end{tabular}

RfD-Reference dose; ing-ingestion; der-dermal, SF-Slope factor
Equation (7) [5] was used to calculate the daily dose of metal absorbed through dermal contact $\left(A D D_{\text {der }}\right)(\mathrm{mg} / \mathrm{kg} /$ day) for non-carcinogenic (nc) metals:

$A D D_{\text {der }-n c}=\frac{C \times A B S \times S A \times S L \times E D \times E F}{A T \times B W} \times 10^{-6}$

Equation (8) [17] was used to calculate the daily dose of metal absorbed through ingestion $\left(A D D_{\text {ing-c }}\right)(\mathrm{mg} / \mathrm{kg} /$ day) for carcinogenic metals:

$A D D_{\text {ing-c }}=\frac{C \times \lg R \times \times E F}{A T} \times 10^{-6}$

Equation (7) was also used to calculate the daily dose of metal absorbed through dermal contact $\left(A D D_{\text {der-c }}\right)(\mathrm{mg} /$ $\mathrm{kg} /$ day) for carcinogenic metals.

Where $C$ is the average heavy metal concentration $(\mathrm{mg} /$ $\mathrm{kg}) ; \lg \mathrm{R}$ is the dust ingestion rate (30 $\mathrm{mg} /$ day) [26]; ED is the exposure duration (6 years) and $\mathrm{EF}$ is the exposure frequency ( 240 days/year). BW is the average body weight of the students $(20.3 \mathrm{~kg})$ [27] and AT is the averaging time ( 1440 days in 6 years) and SA is the exposed skin area $\left(2800 \mathrm{~cm}^{2}\right)$ [28], $\mathrm{SL}$ is the skin adherence factor $(0.2 \mathrm{mg} /$ $\mathrm{cm}^{2} /$ day for children) [28], and ABS is the dermal absorption factor (0.001) [29].

$\mathrm{HQ}$ was calculated through dermal contact and ingestion was calculated for each metal.

Carcinogenic risk is an indication of the probability of an individual developing cancer on exposure to potential carcinogen over a lifetime. Carcinogenic risk (CR) index was calculated for each of these metals using Eq. 9 [30].

$\mathrm{CR}=\mathrm{ADD} * \mathrm{SF}$

where $\mathrm{CR}$ is carcinogenic risks and SF stands for Slope factor. The slope factors used for this study are presented in Table 1.

\subsection{Statistical analysis}

Correlation coefficients were calculated and used to determine the relationship between the metals based on their concentrations. Microsoft Excel version 2013 was used for the statistical calculations.

\section{Results and discussion}

\subsection{Metal concentrations}

The results of analysis for some toxic metals in samples of dust collected from the high schools classrooms $(A-H)$ in $\mathrm{SE}$, Nigeria are shown in Table 2. Also, included are in the Table 2 are some results from schools outside SE Nigeria. The mean levels of the metals in the study area in decreasing order were $\mathrm{Fe}>\mathrm{Zn}>\mathrm{Cr}>\mathrm{Cu}>\mathrm{Ni}>\mathrm{Pb}$. It was observed that the average amount of the metals at the schools in decreasing order was $B>G>H>C>E>A>F>D$. Schools $G$ and $\mathrm{H}$ are in an urban environment where a lot of commercial activities that generate pollution take place. However, School B, which is located in a rural area, had the most elevated toxic metal content. It implies that the extent of pollution of an environment is not determined by only the commercial activities. The level of sanitation awareness and control, state of classroom infrastructure and local environmental policy may contribute to the pollution status. Schools $E$ and $F$ are under a state administration with a different environmental policy, while the others belong to one state administration. Many factors are involved in the complexity of environmental studies. Some factors may be specific to an area which would account for a result of analyte composition in the environmental compartments.

There are no official limits for metals allowable in dust in the Nigerian environment. But permissible limits exist for metals in soil. Therefore, this study used the allowable limits for metals in soils in line with previous published studies on dust in Nigerian environment $[13,17]$.

Among the heavy metals studied, Fe concentrations were the highest at all the classrooms with a range of 3194.76 to $6623.41 \mathrm{mg} / \mathrm{kg}$. Fe can occur from natural origin and anthropogenic sources. Studies have shown that Fe is the predominant metal in the soil of Southeast ecological region of Nigeria [31]. Activities of welders and the wind 
Table 2 Concentrations of metals at selected schools in Southeast Nigeria and comparison

\begin{tabular}{|c|c|c|c|c|c|c|c|c|}
\hline School & & $\mathrm{Cr}$ & $\mathrm{Cu}$ & $\mathrm{Fe}$ & $\mathrm{Ni}$ & $\mathrm{Zn}$ & $\mathrm{Pb}$ & References \\
\hline \multirow[t]{5}{*}{$A$} & Mean & 52.09 & 3.32 & 5712.12 & 28.93 & 205.06 & 30.53 & \multirow[t]{5}{*}{ TW } \\
\hline & SD & 24.33 & 2.91 & 326.33 & 1.26 & 52.84 & 15.57 & \\
\hline & Median & 36.41 & 5.48 & 4894.72 & 35.48 & 197.63 & 19.71 & \\
\hline & Min & 8.73 & 1.07 & 3651.42 & 13.47 & 86.29 & 8.56 & \\
\hline & Max & 75.67 & 8.31 & 6009.67 & 54.85 & 375.27 & 53.94 & \\
\hline \multirow[t]{5}{*}{ B } & Mean & 53.19 & 39.25 & 6125.65 & 42.83 & 270.36 & 39.76 & \multirow[t]{5}{*}{ TW } \\
\hline & SD & 37.99 & 8.55 & 92.24 & 3.29 & 5.48 & 0.38 & \\
\hline & Median & 41.63 & 5.89 & 173.62 & 5.37 & 246.72 & 26.51 & \\
\hline & Min & 37.15 & 25.32 & 5872.31 & 34.62 & 186.25 & 18.64 & \\
\hline & Max & 92.53 & 48.54 & 6251.34 & 53.75 & 293.74 & 53.96 & \\
\hline \multirow[t]{5}{*}{$C$} & Mean & 121.33 & 13.09 & 6144.01 & 14.55 & 7.94 & 15.29 & \multirow[t]{5}{*}{ TW } \\
\hline & SD & 56.81 & 4.96 & 40.63 & 5.23 & 3.21 & 2.54 & \\
\hline & Median & 48.32 & 7.56 & 53.64 & 4.87 & 3.16 & 5.41 & \\
\hline & Min & 92.89 & 2.73 & 5842.91 & 7.94 & 2.64 & 3.95 & \\
\hline & Max & 174.25 & 33.17 & 6324.16 & 29.51 & 12.42 & 26.83 & \\
\hline \multirow[t]{5}{*}{$\mathrm{D}$} & Mean & 95.63 & 3.98 & 5085.02 & 10.46 & 18.35 & 23.89 & \multirow[t]{5}{*}{ TW } \\
\hline & SD & 23.21 & 11.02 & 651.87 & 8.84 & 3.39 & 5.76 & \\
\hline & Median & 48.32 & 6.56 & 1487.36 & 5.27 & 5.83 & 7.57 & \\
\hline & Min & 28.75 & 2.72 & 3594.72 & 4.96 & 4.57 & 5.53 & \\
\hline & Max & 142.83 & 9.45 & 6351.86 & 19.73 & 26.48 & 49.51 & \\
\hline \multirow[t]{5}{*}{$E$} & Mean & 27.03 & 306.55 & 5578.89 & 16.75 & 118.47 & 20.24 & \multirow[t]{5}{*}{ TW } \\
\hline & SD & 0.61 & 240.02 & 241.81 & 12.58 & 115.69 & 0.64 & \\
\hline & Median & 2.89 & 174.77 & 536.83 & 11.74 & 73.56 & 4.97 & \\
\hline & Min & 1.57 & 58.52 & 3194.76 & 6.52 & 41.63 & 2.35 & \\
\hline & Max & 38.31 & 463.28 & 6385.75 & 34.43 & 325.35 & 32.74 & \\
\hline \multirow[t]{5}{*}{$\mathrm{F}$} & Mean & 54.46 & 1.31 & 5779.65 & 13.9 & 90.88 & 30.39 & \multirow[t]{5}{*}{ TW } \\
\hline & SD & 27.34 & 0.02 & 116.28 & 2.16 & 87.76 & 20.21 & \\
\hline & Median & 22.74 & 2.45 & 4353.27 & 15.47 & 93.64 & 23.16 & \\
\hline & Min & 5.53 & 0.74 & 3638.41 & 11.73 & 67.42 & 17.38 & \\
\hline & Max & 67.28 & 3.92 & 5974.26 & 18.45 & 143.91 & 42.62 & \\
\hline \multirow[t]{5}{*}{ G } & Mean & 54.2 & 13.9 & 6064.47 & 120.37 & 91.73 & 20.41 & \multirow[t]{5}{*}{ TW } \\
\hline & SD & 0.01 & 2.65 & 7.93 & 93.58 & 2.68 & 14.25 & \\
\hline & Median & 41.28 & 7.44 & 5847.33 & 95.27 & 75.58 & 12.54 & \\
\hline & Min & 35.85 & 4.91 & 5264.27 & 42.53 & 51.93 & 8.48 & \\
\hline & Max & 63.87 & 16.95 & 6623.41 & 143.98 & 118.32 & 29.36 & \\
\hline \multirow[t]{5}{*}{$\mathrm{H}$} & Mean & 137.79 & 2.66 & 6124.8 & 25.54 & 22.76 & 41.4 & \multirow[t]{5}{*}{ TW } \\
\hline & SD & 18.79 & 0.05 & 42.92 & 1.02 & 15.07 & 29.49 & \\
\hline & Median & 68.35 & 1.68 & 4856.37 & 19.27 & 12.57 & 25.63 & \\
\hline & Min & 67.26 & 0.93 & 3867.45 & 13.23 & 7.83 & 13.58 & \\
\hline & Max & 175.38 & 3.75 & 6583.62 & 34.84 & 32.96 & 57.24 & \\
\hline Nigeria & Range & $15-35$ & NA & NA & $14-35$ & NA & $50-90$ & [13] \\
\hline Nigeria & Range & $0.04-17.37$ & NA & NA & NA & NA & $0.06-85.51$ & [12] \\
\hline Ghana & Range & $0.00-0.93$ & NA & NA & NA & NA & $0.00-0.042$ & [11] \\
\hline Toronto & Mean & 52.3 & 246 & NA & 47.3 & 1353 & 49.0 & [34] \\
\hline
\end{tabular}

TW implies THIS WORK, while NA implies NOT AVAILABLE effect in the dispersion of the ferralitic soil to several locations including the classrooms can contribute to Fe pollution in the environment. Iron is one of the essential metals for humans. Iron consumption in high dosage over a long term may cause hemosiderosis. This condition is characterized when hemosiderin is deposited in large quantity in the liver and other body tissues [32]. It has been discovered that chronic toxicity can lead to aggressive behaviour, 
Table 3 Geoaccumulation Index

\begin{tabular}{|c|c|c|c|c|c|c|c|}
\hline School & & $\mathrm{Cr}$ & $\mathrm{Cu}$ & $\mathrm{Fe}$ & $\mathrm{Ni}$ & $\mathrm{Zn}$ & $\mathrm{Pb}$ \\
\hline \multirow[t]{5}{*}{ A } & Mean & 6.86 & -4.35 & 9.66 & -1.84 & 0.53 & 0.03 \\
\hline & SD & 5.76 & -4.54 & 5.53 & -6.64 & -1.43 & -0.97 \\
\hline & Median & 6.34 & -3.63 & 9.44 & -1.51 & 0.48 & -0.61 \\
\hline & Min & 4.28 & -5.97 & 9.02 & -2.94 & -0.56 & -1.81 \\
\hline & Max & 7.39 & -3.02 & 9.74 & -0.89 & 1.4 & 0.85 \\
\hline \multirow[t]{5}{*}{ B } & Mean & 6.89 & -0.79 & 9.76 & -1.25 & 0.93 & 0.41 \\
\hline & SD & 6.4 & -2.98 & 3.71 & -5.06 & -4.64 & -6.64 \\
\hline & Median & 6.53 & -3.52 & 4.62 & -4.32 & 0.79 & -0.18 \\
\hline & Min & 6.37 & 1.42 & 9.7 & -1.56 & 0.39 & -0.69 \\
\hline & Max & 7.68 & -0.47 & 9.79 & -0.92 & 1.04 & 0.85 \\
\hline \multirow[t]{5}{*}{$C$} & Mean & 8.08 & -2.4 & 9.77 & -2.84 & -4.06 & -0.97 \\
\hline & SD & 6.98 & -3.78 & 2.53 & -4.32 & -5.64 & -3.64 \\
\hline & Median & 6.75 & -3.16 & 2.93 & -4.32 & -5.64 & -2.47 \\
\hline & Min & 7.69 & -4.64 & 9.7 & -3.64 & -5.64 & -2.94 \\
\hline & Max & 8.6 & -1.03 & 9.81 & -1.79 & -3.47 & -0.17 \\
\hline \multirow[t]{5}{*}{$D$} & Mean & 7.73 & -4.06 & 9.5 & -3.32 & -2.94 & -0.33 \\
\hline & SD & 5.69 & -2.64 & 6.53 & -3.47 & -5.64 & -2.4 \\
\hline & Median & 6.75 & -3.37 & 7.72 & --4.32 & -4.64 & -2 \\
\hline & Min & 6 & -4.64 & 8.99 & -4.32 & -5.06 & -2.47 \\
\hline & Max & 8.31 & -2.84 & 9.82 & -2.4 & -2.4 & 0.72 \\
\hline \multirow[t]{5}{*}{$E$} & Mean & 5.91 & 2.18 & 9.63 & -2.64 & -0.27 & -0.58 \\
\hline & SD & 0.44 & 1.83 & 5.1 & -3.06 & -0.3 & -5.64 \\
\hline & Median & 2.68 & 1.37 & 6.25 & -3.06 & -0.94 & -2.56 \\
\hline & Min & 1.8 & -0.2 & 8.82 & -4.06 & -1.79 & -3.64 \\
\hline & Max & 6.41 & 2.78 & 9.82 & -1.56 & 1.19 & 0.12 \\
\hline \multirow[t]{5}{*}{$\mathrm{F}$} & Mean & 6.92 & -5.72 & 9.68 & -2.84 & -0.64 & 0.01 \\
\hline & SD & 5.93 & -11.72 & 4.04 & -5.64 & -0.69 & -0.58 \\
\hline & Median & 5.66 & -4.8 & 9.27 & -2.74 & -0.6 & -0.38 \\
\hline & Min & 3.62 & -6.64 & 9.01 & -3.06 & -1.09 & -0.79 \\
\hline & Max & 7.22 & -4.06 & 9.73 & -2.47 & 0.01 & 0.51 \\
\hline \multirow[t]{5}{*}{ G } & Mean & 6.91 & -2.25 & 9.75 & 0.24 & -0.64 & -0.56 \\
\hline & SD & -5.64 & -4.64 & 0.16 & -0.12 & -5.64 & -1.06 \\
\hline & Median & 6.52 & -3.18 & 9.7 & -0.1 & -0.92 & -1.25 \\
\hline & Min & 6.32 & -3.84 & 9.54 & -1.25 & -1.47 & -1.84 \\
\hline & Max & 7.15 & -2 & 9.88 & 0.5 & -0.27 & -0.03 \\
\hline \multirow[t]{5}{*}{$\mathrm{H}$} & Mean & 8.26 & -4.64 & 9.76 & -2 & -2.64 & 0.46 \\
\hline & SD & 5.38 & -10.4 & 2.61 & -6.64 & -3.18 & -8.77 \\
\hline & Median & 7.25 & -5.64 & 9.43 & -2.4 & -3.51 & -0.23 \\
\hline & Min & 7.22 & -6.64 & 9.1 & -2.94 & -4.32 & -1.15 \\
\hline & Max & 8.61 & -4.06 & 9.87 & -1.56 & -2.12 & -1.15 \\
\hline
\end{tabular}

fatigue, anorexia, arthritis, gut damage, headaches, heart disease, histamine, hyperactivity, liver damage, increased oxidative stress and blood levels of serotonin, metabolic acidosis, and loss of weight [33].

The average level of $\mathrm{Zn}$ in the study ranged from 2.64 to $375.27 \mathrm{mg} / \mathrm{kg}$. This is less than the $1353.0 \mathrm{mg} / \mathrm{kg}$ observed in Toronto classrooms [34]. The sources of $Z n$ vary from paints, roofing materials and soil to infiltration of trafficcontaminated outdoor dust [35]. $\mathrm{Zn}$ is classified as an essential metal. However, exposure to very high concentration of $Z n$ or its deficiency may enhance susceptibility to carcinogens [36]. The level of $Z n$ at Schools $A$ and B were higher than the permissible limit for $\mathrm{Zn}$ in Nigeria which is $140 \mathrm{mg} / \mathrm{kg}$ [37].

The range of concentrations of $\mathrm{Cr}$ in the samples was $1.57-175.38 \mathrm{mg} / \mathrm{kg}$. The sources may probably be due to activities involving steel works at the vicinity of some of the schools. Schools $\mathrm{C}$ and $\mathrm{H}$ had levels higher than 
Table 4 Contamination factors (CF) and Pollution load index (PLI)

\begin{tabular}{lcclcccc}
\hline School & $\mathrm{Cr}$ & $\mathrm{Cu}$ & $\mathrm{Fe}$ & $\mathrm{Ni}$ & $\mathrm{Zn}$ & $\mathrm{Pb}$ & $\mathrm{PLI}$ \\
\hline $\mathrm{A}$ & 173.63 & 0.07 & 1215.32 & 0.43 & 2.16 & 1.53 & $20,990.71$ \\
$\mathrm{~B}$ & 177.3 & 0.87 & 1303.33 & 0.63 & 2.85 & 1.99 & $718,324.8$ \\
$\mathrm{C}$ & 90.1 & 6.81 & 1187 & 0.25 & 1.25 & 1.01 & $229,876.2$ \\
$\mathrm{D}$ & 181.53 & 0.03 & 1229.71 & 0.2 & 0.96 & 1.52 & 1954.417 \\
$\mathrm{E}$ & 180.67 & 0.31 & 1290.31 & 1.77 & 0.97 & 1.02 & $126,557.2$ \\
$\mathrm{~F}$ & 459.3 & 0.06 & 1303.15 & 0.38 & 0.24 & 2.07 & 6779.65 \\
$\mathrm{G}$ & 404.43 & 0.29 & 1307.24 & 0.21 & 0.08 & 0.76 & 1957.58 \\
$\mathrm{H}$ & 7.73 & -4.08 & 9.49 & -3.28 & -2.95 & -0.33 & 955.687 \\
\hline
\end{tabular}

Note: $\mathrm{CF}<1$, Low contamination; $1 \leq \mathrm{CF}<3$, Moderate contamination; $3 \leq \mathrm{CF} \leq 6$, Considerable contamination; CF $>6$, High contamination [18]
$100 \mathrm{mg} / \mathrm{kg}$ [37] which was the permissible safe limit for $\mathrm{Cr}$ in Nigeria. The average level for the study was $74.47 \mathrm{mg} / \mathrm{kg}$ which is higher than in Toronto schools $(52.3 \mathrm{mg} / \mathrm{kg}$ ) and Lagos high density schools $(10.53 \mathrm{mg} / \mathrm{kg})$. It is higher than the mean concentration of chromium in the earth's crust which is $0.2 \mu \mathrm{g} / \mathrm{g}$ [38]. This suggests that the chromium was introduced from anthropogenic sources. The carcinogenicity is linked with inhalation of $\mathrm{Cr}(\mathrm{VI})$ compounds [39]. Chromium is also an essential element which is important for normal glucose metabolism but chromium(VI) is highly toxic [40] because of their oxidizing properties through the cell membranes [41]. Skin contact with high level of chromium has been known to produce contact dermatitis [42].

The mean concentration range of $\mathrm{Cu}$ was 0.93-463.28. Levels above the permissible limit of $20 \mathrm{mg} / \mathrm{kg}$ [37] were observed in Schools B and E. The average for this study is $40.01 \mathrm{mg} / \mathrm{kg}$ which is lower than the level at Toronto schools $(246.0 \mathrm{mg} / \mathrm{kg})$.

The International Agency for Research on Cancer (IARC) has reported that nickel compounds are carcinogenic to humans and metallic nickel is probably carcinogenic to humans [43]. Nickel was among the trace metals detected in the classroom dusts. It ranged from 4.96 to $143.98 \mathrm{mg} /$ $\mathrm{kg}$ in the samples studied, with Schools A and G exceeding the permissible limit of $35 \mathrm{mg} / \mathrm{kg}$ [37]. The average for this study is $34.17 \mathrm{mg} / \mathrm{kg}$. This is near to the levels at Southsouth, Nigeria schools at $35 \mathrm{mg} / \mathrm{kg}$ [13] but lower than the level at Toronto schools at $47.3 \mathrm{mg} / \mathrm{kg}$. One of the sources of $\mathrm{Ni}$ in classrooms is from infiltration from outdoor contaminated particulate matter [44].

The average level of $\mathrm{Pb}$ in this study is $27.74 \mathrm{mg} / \mathrm{kg}$, from a range $2.35-53.96 \mathrm{mg} / \mathrm{kg}$. The sources of $\mathrm{Pb}$ include paint and vehicular emissions from the use of leaded petroleum products. $\mathrm{Pb}$ may have accumulated in the classroom dusts due to the paints used in some of the schools. Paint flakes were observed on the floors in some of the classrooms. Adebamowo et al. [45] reported that most emulsion and gloss paints produced in Nigeria had high levels of lead. At $85 \mathrm{mg} / \mathrm{kg}$ permissible limit [37], the observed level of $\mathrm{Pb}$ at all the studied schools was below the limit. This level may be attributed to the location of some of the schools which were with low vehicular movement that would have emitted lead from fuel. Some of the classrooms were not painted or the paint flakes may have peeled off over time. The levels at Toronto schools $(49.0 \mathrm{mg} / \mathrm{kg})$, Lagos high density schools $(23.89 \mathrm{mg} / \mathrm{kg})$ and Ghana schools $(0.0482 \mathrm{mg} / \mathrm{kg}$ ) were also low. Lead is a non-volatile toxic metal that affects various systems of the body, such as the cardiovascular, gastrointestinal, hematologic, neurologic and renal systems. Young people, especially children are mostly at higher risk on exposure to lead even at low levels as this can cause serious learning disabilities, seizures, or even death. [46].

The mean, median and standard deviations of concentrations of the metals as shown in Table 2 did not follow a pattern. The mean was used for the discussion as it was observed however that the median and the standard deviations were lower than the mean values in most of the study areas.

The degree of toxicity of toxic metals to humans depends on considerations like the type of metal, dosage of the metal absorbed, length of time and route of exposure, and age of the individual [47].

\subsection{Contamination status}

The levels of contamination based on the calculation of the Igeo and the CF for the studied schools are given in Tables 3 and 4.

\subsubsection{Geoaccumulation index}

Thegeo-accumulation index values for the studied sites are presented in Table 3. The interpretation of Igeo values by Muller [16] was applied in this study. The values 
of Igeo for $\mathrm{Cu}$ are negative at all schools except School $\mathrm{C}$. The values for $\mathrm{Ni}$ are negative at all the schools except School $\mathrm{E}$, while they are also negative for $\mathrm{Pb}$ and $\mathrm{Zn}$ except at Schools $A$ and $B$ which were unpolluted to moderately polluted $(0 \leq \operatorname{lgeo}<1)$. Based on the classification by Muller [16], these negative values imply that the environment is unpolluted with the metals. All the schools were very strongly polluted with $\mathrm{Fe}$ (Igeo $\geq 5$, Very strongly polluted), strongly polluted to very strongly polluted with $\mathrm{Cr}$, since they had positive Igeo values.

\subsubsection{Contamination factor}

The pollution intensity or contamination status was assessed using the proposal by Forstner and Wittmann [18]. This was based on the calculated CF values as presented in Table 4. At all the schools, the average concentrations indicated that $\mathrm{Ni}$ had a low contamination status (CF < 1) except at School E (moderate contamination), while $\mathrm{Cu}$ had a low contamination status except at School C. There was moderate contamination by $\mathrm{Pb}$ at all the schools except at Schools $\mathrm{G}$ and $\mathrm{H}$ (low contamination). All the schools are highly contaminated with $\mathrm{Cr}$ and $\mathrm{Fe}(\mathrm{CF}>6)$. Fe had the maximum value of $\mathrm{CF}$ at School G (1307.24), while the lowest CF value observed was by $\mathrm{Cu}$ at School $\mathrm{H}(-4.08)$. The mean $\mathrm{CF}$ values for the investigated metals in this study were in the order: $\mathrm{Fe}>\mathrm{Cr}>\mathrm{Pb}>\mathrm{Zn}>\mathrm{Cu}>\mathrm{Ni}$.

\subsubsection{Pollution load index}

The pollution load index based on the proposal by Tomllinson et al. [20], show that the PLI was greater than unity in all the studied schools as presented in Table 4. The PLI values ranged from 9555.69 to $718,324.8$. This indicates that the dusts were polluted by the heavy metals. It also implies that the quality of the classrooms was deteriorated. The deterioration of site quality, in descending order, was $B>C>E>A>F>G>D>H$. Thus, School B had the worst deterioration of site quality.

\subsection{Assessment of potential health risk}

The results of calculated Average Daily Dose (ADD), $\mathrm{HQ}_{\text {ing, }}$ and $\mathrm{HQ}_{\text {der }}$ are presented in Tables 5 and 6 respectively. The calculated values of $\mathrm{HQ}_{\text {ing }}$ for each of the selected metals except $\mathrm{Pb}$ at School B were less than one. This indicates that ingestion of dust at the classrooms except at School B would have no significant non-carcinogenic harmful effects on the health of the students $[48,49]$. However, dermal contact with the dust at all the classrooms would expose students to adverse

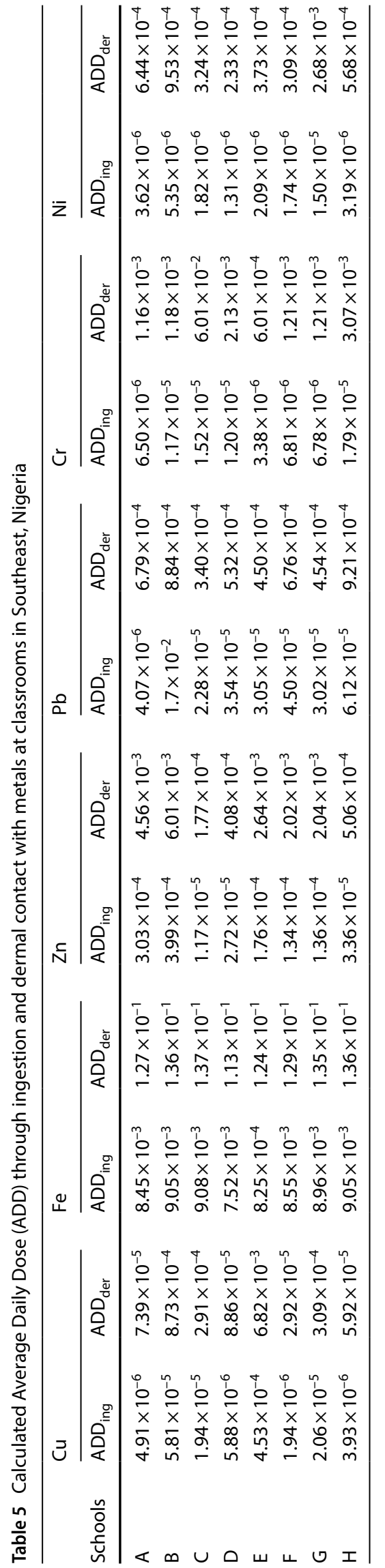

SN Applied Sciences a SPRINGER NATURE journal 
Table 6 Noncarcinogenic risk of metals in classroom dust

\begin{tabular}{|c|c|c|c|c|c|c|c|c|}
\hline \multirow[b]{2}{*}{ School } & \multicolumn{2}{|l|}{$\mathrm{Cu}$} & \multicolumn{2}{|l|}{$\mathrm{Fe}$} & \multicolumn{2}{|l|}{$\mathrm{Zn}$} & \multicolumn{2}{|l|}{$\mathrm{Pb}$} \\
\hline & $\mathrm{HQ}_{\text {ing }}$ & $\mathrm{HQ}_{\mathrm{der}}$ & $\mathrm{HQ}_{\text {ing }}$ & $\mathrm{HQ}_{\mathrm{der}}$ & $\mathrm{HQ}_{\text {ing }}$ & $\mathrm{HQ}_{\mathrm{der}}$ & $\mathrm{HQ}_{\text {ing }}$ & $\mathrm{HQ}_{\mathrm{der}}$ \\
\hline A & $1.23 \times 10^{-4}$ & $6.16 \times 10^{-3}$ & $1.21 \times 10^{-2}$ & 2.12 & $1.01 \times 10^{-3}$ & $7.60 \times 10^{-2}$ & $1.16 \times 10^{-3}$ & 1.29 \\
\hline B & $1.45 \times 10^{-3}$ & $7.28 \times 10^{-2}$ & $1.29 \times 10^{-2}$ & 2.27 & $1.33 \times 10^{-3}$ & $1.00 \times 10^{-1}$ & 4.8571429 & 1.68 \\
\hline$C$ & $4.85 \times 10^{-4}$ & $2.43 \times 10^{-2}$ & $1.30 \times 10^{-2}$ & 2.28 & $3.90 \times 10^{-5}$ & $2.95 \times 10^{-3}$ & $6.51 \times 10^{-3}$ & $6.48 \times 10^{-1}$ \\
\hline $\mathrm{D}$ & $1.47 \times 10^{-4}$ & $7.38 \times 10^{-3}$ & $1.07 \times 10^{-4}$ & 1.88 & $9.07 \times 10^{-5}$ & $6.80 \times 10^{-3}$ & $1.01 \times 10^{-2}$ & 1.01 \\
\hline E & $1.00 \times 10^{-2}$ & $5.68 \times 10^{-1}$ & $1.18 \times 10^{-3}$ & 2.07 & $5.87 \times 10^{-4}$ & $4.40 \times 10^{-2}$ & $8.71 \times 10^{-3}$ & $8.57 \times 10^{-1}$ \\
\hline $\mathrm{F}$ & $4.85 \times 10^{-5}$ & $2.43 \times 10^{-3}$ & $1.22 \times 10^{-2}$ & 2.15 & $4.47 \times 10^{-4}$ & $3.37 \times 10^{-2}$ & $1.29 \times 10^{-2}$ & 1.29 \\
\hline G & $5.15 \times 10^{-4}$ & $2.58 \times 10^{-2}$ & $1.28 \times 10^{-2}$ & 2.25 & $4.53 \times 10^{-4}$ & $3.40 \times 10^{-2}$ & $8.63 \times 10^{-3}$ & $8.65 \times 10^{-1}$ \\
\hline $\mathrm{H}$ & $9.83 \times 10^{-5}$ & $4.93 \times 10^{-3}$ & $1.29 \times 10^{-2}$ & 2.27 & $1.12 \times 10^{-4}$ & $8.43 \times 10^{-3}$ & $1.75 \times 10^{-2}$ & 1.75 \\
\hline
\end{tabular}

Table 7 Carcinogenic risk of metals through ingestion of dust

\begin{tabular}{llll}
\hline School & $\begin{array}{l}\mathrm{Cr} \\
\mathrm{CR}_{\text {ing }}\end{array}$ & $\begin{array}{l}\mathrm{Ni} \\
\mathrm{CR}_{\text {ing }}\end{array}$ & $\begin{array}{l}\mathrm{Pb} \\
\mathrm{CR}_{\text {ing }}\end{array}$ \\
\hline $\mathrm{A}$ & $1.30 \times 10^{-5}$ & $3.98 \times 10^{-6}$ & $9.88 \times 10^{-5}$ \\
$\mathrm{~B}$ & $2.34 \times 10^{-5}$ & $5.88 \times 10^{-6}$ & $4.13 \times 10^{-2}$ \\
$\mathrm{C}$ & $3.04 \times 10^{-5}$ & $2.00 \times 10^{-6}$ & $5.54 \times 10^{-5}$ \\
$\mathrm{D}$ & $2.40 \times 10^{-5}$ & $1.44 \times 10^{-6}$ & $8.60 \times 10^{-5}$ \\
$\mathrm{E}$ & $6.76 \times 10^{-6}$ & $2.30 \times 10^{-6}$ & $7.41 \times 10^{-5}$ \\
$\mathrm{~F}$ & $1.36 \times 10^{-5}$ & $1.91 \times 10^{-6}$ & $1.09 \times 10^{-4}$ \\
$\mathrm{G}$ & $1.36 \times 10^{-5}$ & $1.65 \times 10^{-6}$ & $7.33 \times 10^{-5}$ \\
$\mathrm{H}$ & $3.58 \times 10^{-5}$ & $3.51 \times 10^{-6}$ & $1.49 \times 10^{-4}$ \\
\hline
\end{tabular}

effects of Fe. There will be adverse effect due to $\mathrm{Pb}$ for dermal contact with dust at Schools A, B, D, F and $H$ since the $\mathrm{H}_{\text {der }}$ is greater than one. Dermal contact with dust at Schools C, E and G would have no significant risk of non-carcinogenic harmful effects on the health of the students.

The calculation for carcinogenic risk assessment is presented in Table 7. Ingestion of dust particles at classrooms in all the schools would have no carcinogenic effect due to $\mathrm{Cr}$ and $\mathrm{Pbas}$ the cancer risk values were within the cancer tolerable range of $10^{-6}$ to $10^{-4}$ [50]. But ingestion of dust particles at classrooms in all the studied schools would pose a carcinogenic risk due to $\mathrm{Ni}$. This is due to the values from the calculation for cancer risk, which were outside the cancer tolerable range of $10^{-6}$ to $10^{-4}[50]$.
From the above results, there is pollution of the dusts in the classrooms by heavy metals at different levels raising health concerns.

\subsection{Correlation analysis}

Table 8 shows the correlation coefficients between metal concentrations in the dust samples. Significant correlation may be used to indicate heavy metals that originated from the same source [51]. There were positive coefficients observed for $\mathrm{Cr} / \mathrm{Fe}(0.218), \mathrm{Cr} / \mathrm{Pb}$ (0.129), $\mathrm{Cu} / \mathrm{Zn}(0.139)$, $\mathrm{Fe} / \mathrm{Ni}(0.4), \mathrm{Fe} / \mathrm{Zn}(0.169), \mathrm{Fe} / \mathrm{Pb}(0.254), \mathrm{Ni} / \mathrm{Zn}(0.188)$ and $\mathrm{Zn} / \mathrm{Pb}$ (0.426). Negative correlations existed between the following metal pairs: $\mathrm{Cr} / \mathrm{Cu}(-0.515), \mathrm{Cr} / \mathrm{Ni}(-0.256), \mathrm{Cr} /$ $\mathrm{Cu}(-0.218), \mathrm{Cu} / \mathrm{Ni}(-0.157), \mathrm{Cu} / \mathrm{Pb}(-0.296)$, and $\mathrm{Ni} / \mathrm{Pb}$ $(-0.103)$. No significant correlation existed between the metals at 0.01 levels (two tailed). The indication is that the metals in the dusts may have originated from different pollution sources.

This study used elemental concentrations in the dust samples to obtain a first and precautionary estimate of the health risk associated with the dermal and oral intake of dusts. Using total elemental concentrations as exposure indicators can be regarded as a limitation of this study because in the digestive system, the degree of solubilization aries from metal to metal, and therefore an estimate of the bioavailable or bioaccessible fraction should provide a better metric in the investigation of its potential health impact than its total concentration. Moreover, there are
Table 8 Correlation coefficients between metals

\begin{tabular}{lllllll}
\hline & $\mathrm{Cr}$ & $\mathrm{Cu}$ & $\mathrm{Fe}$ & $\mathrm{Ni}$ & $\mathrm{Zn}$ & $\mathrm{Pb}$ \\
\hline $\mathrm{Cr}$ & 1 & & & & & \\
$\mathrm{Cu}$ & -0.518 & 1 & & & & \\
$\mathrm{Fe}$ & 0.218 & -0.218 & 1 & & & \\
$\mathrm{Ni}$ & -0.256 & -0.157 & 0.4 & 1 & 1 & \\
$\mathrm{Zn}$ & -0.68 & 0.139 & 0.169 & 0.188 & 0.426 & 1 \\
$\mathrm{~Pb}$ & 0.129 & -0.296 & 0.254 & -0.103 & \\
\hline
\end{tabular}


other methods such as mechanistic models that should provide better estimates of dust and soil ingestion rates.

Adverse health effects from exposure to dusts make it imperative for policies that would reduce its entry into classrooms. These would include construction of the school buildings with appropriate doors and windows, fixing of dust filters on classroom doors and windows as well as regular cleaning and repainting of the classrooms. Some activities that may generate dusts may be restricted to reasonable distances from schools. Proper maintenance of the school buildings, including fixing of damaged doors, ceilings and windows are also recommended. Healthy environmental practices should be imbibed including wearing of protective cloths and cleaning of food before ingestion.

\section{Conclusions}

The mean levels of the metals in the study area in decreasing order were $\mathrm{Fe}>\mathrm{Zn}>\mathrm{Cr}>\mathrm{Cu}>\mathrm{Ni}>\mathrm{Pb}$. It was observed that the average amount of the metals at the schools in decreasing order was $\mathrm{B}>\mathrm{G}>\mathrm{H}>\mathrm{C}>\mathrm{E}>\mathrm{A}>\mathrm{F}>\mathrm{D}$. School $\mathrm{B}$ is in a rural area, while schools $\mathrm{G}$ and $\mathrm{H}$ are in an urban environment. The findings indicated that all the classrooms were contaminated at different levels with the selected metals. The degree of pollution of the classrooms ranged from low contamination due to $\mathrm{Cu}$ and strong contamination due to Fe. It was found that ingestion of dust in the classrooms posed no significant non-carcinogenic risk on the students' health. There was carcinogenic risk for ingestion of the dusts due to Ni. Dermal contact posed significant non-carcinogenic health risk at some schools. Exposure to these toxic metals may cause adverse health effects depending on the total dose absorbed, level, route of exposure and age of the person. The sources of the metals varied. Measures to monitor and reduce exposure to dust in the classrooms are required. These may include constructing classrooms with appropriate dust traps, regular cleaning and maintenance of the school environment and regulation of activities in the vicinity of the schools to improve the quality of the environment.

Acknowledgements The assistance of Mrs. Ngozi Alumona and Mr. Wilson Kenechukwu in sample collection is acknowledged. Dr. Cynthia Ibeto is hereby acknowledged for proofreading this manuscript

Funding The research was not funded by any institution. It was funded by the researchers.

Availability of data and material Not applicable.

Code availability Not applicable.

\section{Compliance with ethical standards}

Conflict of interest The authors declare that they have no conflict of interest.

Open Access This article is licensed under a Creative Commons Attribution 4.0 International License, which permits use, sharing, adaptation, distribution and reproduction in any medium or format, as long as you give appropriate credit to the original author(s) and the source, provide a link to the Creative Commons licence, and indicate if changes were made. The images or other third party material in this article are included in the article's Creative Commons licence, unless indicated otherwise in a credit line to the material. If material is not included in the article's Creative Commons licence and your intended use is not permitted by statutory regulation or exceeds the permitted use, you will need to obtain permission directly from the copyright holder. To view a copy of this licence, visit http://creativecommons .org/licenses/by/4.0/.

\section{References}

1. IUPAC (1990) Glossary of atmospheric chemistry terms. International Union of Pure and Applied Chemistry, Applied Chemistry Division, Commission on Atmospheric Chemistry. Pure Appl Chem 62(11):2167-2219

2. Harris MA (2016) Geobiotechnological solutions to anthropogenic disturbances: a Caribbean perspective. Environ Earth Sci Switz. https://doi.org/10.1007/978-3-319-30465-6_1

3. Pope CA III, Burnett RT, ThunMJ CEE, KrewskiD IK, Thruston GD (2002) Lung cancer, cardiopulmonary mortality and longterm exposure to fine particulate air pollution. J Am Med Assoc 287:1132-1141

4. Zhou Y, Levy Jl, Hammitt JK, Evans JS (2003) Estimating population exposure to power plant emissions using CALPUFF: a case study in Beijing, China. Atmos Environ 37:815-826. https://doi. org/10.1016/S1352-231(02)00937-8

5. Xu X, Lu X, Han X, Zhao N (2015) Ecological and health risk assessment of metal in resuspended particles of urban street dust from an industrial city in China. Curr Sci 108(1):72-79

6. Tong ST, Lam KC (2000) Home sweet home? A case study of household dust contamination in Hong Kong. Sci Total Environ 256(2-3):115-123. https://doi.org/10.1016/s0048 -9697(00)00471-X

7. Huang M, Wang W, Chan CY et al (2014) Contamination and risk assessment (based on bio accessibility via ingestion and inhalation) of metal (loid)s in outdoor and indoor particles from urban centers of Guangzhou, China. Sci Total Environ 480:117-124. https://doi.org/10.1016/j.scitotenv.2014.01.115

8. Taiwo AM, Awomeso JA, Taiwo OT, Oremodu BD et al (2017) Assessment of health risks associated with road dusts in major traffic hotspots in Abeokuta metropolis, Ogun state, southwestern Nigeria. Stoch Environ Res Risk Assess 31:431-447. https:// doi.org/10.1007/s00477-016-1302-y

9. Zheng N, Liu J, Wang Q, Liang Z (2010) Health risk assessment of heavy metal exposure to street dust in the zinc smelting district, Northeast of China. Sci Total Environ 408(4):726-733

10. Al-Khashman OA (2007) Determination of metal accumulation in deposited street dusts in Amman, Jordan. Environ Geochem Health 29(1):1-10. https://doi.org/10.1007/s10653-006-9067-8

11. Nkansah MA, Fianko JR, Mensah S et al (2015) Determination of heavy metals in dust from selected nursery and kindergarten 
classrooms within the Kumasi metropolis of Ghana. Cogent Chem. https://doi.org/10.1080/23312009.2015.1119005

12. Popoola O, Bamgbose O, Okonkwo O et al (2012) Heavy metals content in classroom dust of some public primary schools in metropolitan Lagos, Nigeria. Res J Environ Earth Sci 4:460-465

13. Agbaire PO, Odali EW, Iniaghe PO (2019) Concentrations and risk assessment of selected heavy metals in indoor dust of primary schools in delta state. Niger Niger J Sci Res (NJSR) 18(3):187-194

14. WHO (1999) Hazard prevention and control in the work environment: airborne dust. World Health Organization. https://apps. who.int/iris/handle/10665/66147. Accessed 21 Mar 2020.

15. Iqbal J, Shah MH (2011) Distribution, correlation and risk assessment of selected metals in urban soils from Islamabad. Pak J Hazard Mater 192(2):887-898. https://doi.org/10.1016/j.jhazm at.2011.05.105

16. Muller G (1979) Schwermetalle in den sediment des Rheins, Veranderungem Seit. Umschau 79:778-783

17. Iwegbue CMA, Obi G, Emoyan OO, Odali EW et al (2018) Characterization of metals in indoor dusts from electronic workshops, cybercafés and offices in southern Nigeria: implications for onsite humanexposure. Ecotoxicol Environ Saf 159:342-353. https ://doi.org/10.1016/j.ecoenv.2018.04.070

18. Forstner U, Wittmann GTW (1983) Metal pollution in aquatic environment. Springer, New York

19. Angulo E (1996) The Tomlinson pollution load index applied to heavy metals "mussel-watch" data: a useful index to assess coastal pollution. Sci Total Environ 187:19-56. https://doi. org/10.1016/0048-9697(96)05128-5

20. Tomllinson DC, Wilson JG, Harris CR, Jeffery DW (1980). Problems in the Assessment of Heavy metals levels in Estuaries and the formation of pollution index. HelgolanderWissenschaftlicheMeeresuntersUchunge 33: 566-569.

21. Luo XS, Ding J, Xu B, Wang YJ, Li HB (2012) Incorporating bio accessibility into human health risk assessments of heavy metals in urban park soils. Sci Total Environ 424:88-96. https://doi. org/10.1016/j.scitotenv.2012.02.053

22. Kavcar P, Sofuoglu S (2009) A health risk assessment for exposure to tracemetals via drinking water ingestion pathway. Int J Hyg Environ Health 212(2):216-227. https://doi.org/10.1016/j. ijheh.2008.05.002

23. Harmanescu M, Alda LM, Bordean DM et al (2011) Heavy metals health risk assessment for population via consumption of vegetables grown in old mining area; a case study: Banat County, Romania. Chem Cent J 5:64. https://doi. org/10.1186/1752-153X-5-64

24. Kamunda C, Mathuthu M, Madhuku M (2016) Health risk assessment of heavy metals in soils from Witwatersrand gold mining basin, South Africa. Int J Environ Res Public Health 13(7):663. https://doi.org/10.3390/ijerph13070663

25. Ogbo AB, Patrick-Iwuanyanwu K (2019) Heavy metals contamination and potential human health risk via consumption of vegetables from selected communities in ONELGA, Rivers State, Nigeria. Eur J Nutr Food Saf 9(2):134-151

26. USEPA (2017) Soil and dust ingestion, update for chapter 5 of the exposure factors handbook, EPA/600/R-17/384F. National Center for Environmental Assessment Office of Research and Development U.S. Environmental Protection Agency, Washington, p 20460

27. De Onis M, Onyango A, Borghi E (2009) Development of a WHO growth reference for school-aged children and adolescents. Bull World Health Organ 85:660-667. https://doi.org/10.2471/ blt.07.043497

28. Durowoju OS, Edokpayi JN, Popoola OE, Odujo JO (2018) Health risk assessment of heavy metals on primary school learners from dust and soil within school premises in Lagos State, Nigeria. In:
Saleh HE, Aglan R (eds) Heavy metals. IntechOpen, London, pp 319-336. https://doi.org/10.5772/intechopen.74741

29. Ferreira-Baptista L, De Miguel E (2005) Geochemistry and risk assessment of streetdust in Luanda, Angola: a tropical urban environment. Atmos Environ 39:4501-4512. https://doi. org/10.1016/j.atmosenv.2005.03.026

30. US EPA (1989) Risk assessment guidance for Superfund. Vol. I: human health evaluation manual. EPA/540/1- 89/002. Office of Solid Waste and Emergency Response, Washington DC.

31. Okoye COB, Agbo KE (2011) Dispersion pattern of trace metals in soils surrounding solid waste dumps in Nsukka. J Chem Soc Nigeria 36(2):112-119

32. Hoffman Center Staff. Iron: deficiency and toxicity. http://www. drhoffman.com/page.cfm/120. Accessed 24 Jan 2020

33. Vital health zone (2020) All about minerals: Iron. http://www. vitalhealthzone.com. Accessed 3 Mar 2020.

34. AlHejami A (1995) Heavy metals in indoor settled dusts in Toronto, Canada. Thesis, Al-Nahrain University, Baghdad, Iraq

35. Iwegbue CMA (2014) Impact of land use types on the concentrations of metals in soils of urban environment in Nigeria. Environ Earth Sci 72:4567-4585. https://doi.org/10.1007/s1266 5-014-3355-x

36. Bellies RP (1994) The metals. In: Clayton G, Clayton FE (eds) Patty's industrial hygiene and toxicology, vol 2, part C, 4th edn. Wiley, New York

37. Department of Petroleum Resources (DPR) (2002) Environmental guidelines and standards for the petroleum industry in Nigeria, revised. Ministry of Petroleum and Mineral Resources, Abuja

38. Katz SA, Salem H (1993) The toxicology of chromium with respect to its chemical speciation: a review. J Appl Toxicol 13(3):217-224. https://doi.org/10.1002/jat.2550130314

39. Wilbur S, AbadinH, Fay M et al. Toxicological Profile for Chromium. Agency for Toxic Substances and Disease Registry (US). Health effects. http://www.ncbi.nlm.nih.gov/books/NBK15 8851/. Accessed 3 Mar 2020

40. Costa M, Klein CB (1997) Toxicity and carcinogenity of $\mathrm{Cr}(\mathrm{VI})$ in animal models and humans. Crit Rev Toxicol 27(5):431-442. https://doi.org/10.1080/10408440500534032

41. Codex Alimentarius Commission (1995) Joint FAO/WHO Food Standards Programme. Codex general standard for contaminants and toxins in foods. Doc. no. CX/FAC 96/17. Codex Alimentarius Commission, Geneva.

42. Bruynzeel DP, Hennipman G (1988) Irritant contact dermatitis and chrome-passivatedmetal. Contact Derm 19(3):175-179. https://doi.org/10.1111/j.1600-0536-1988.tbo2889.X

43. IARC (1990) Chromium, nickel, and welding. IARC monographs on the evaluation of carcinogenic risks to humans, vol 49 . International Agency for Research on Cancer, Lyon, France

44. Hassan SKM (2012) Metal concentrations and distribution in the household, stairs and entry way dust of some Egyptian homes. Atmos Environ 54:207-215. https://doi.org/10.1016/j.atmos env.2012.02.013

45. Adebamowo EO, Agbede OA, Sridhar MKC, Adebamowo CA (2006) An evaluation of lead levels in residential paints sold in Nigeria markets. Indoor Built Environ 15:551-554. https://doi. org/10.1177/1420326x06072992

46. WHO (2010) Preventing diseases through healthy environment. Action is needed on chemicals of major public health concern, public health and environment. World Health Organization, Geneva

47. Ihedioha JN, Okoye COB, Onyechi UA (2014) Health risk assessment of zinc, chromium and nickel from cow meat consumption in an urban Nigerian population. Int J Occup Environ Health 20(4):281-288. https://doi.org/10.1179/2049396714Y.00000 00075 
48. Iqbal J, Shah MH (2013) Health risk assessment of metals in surface water from freshwater source lakes. Pak Hum Ecol Risk Assess 19(6):1530-1543. https://doi.org/10.1080/10807 039.2012 .71681

49. Huang M, Zhou S (2008) Heavy metals in vegetables: assessment of potential health risk for inhabitants in Khunshan China. Sci Total Environ 405:54-61

50. USEPA (1997) Exposure factors handbook, EPA/600/p-95/002 Fa, b, c. Office of research and development. Environmental Protection Agency, Washington
51. Ahamad Ml, Song J, Sun H et al (2020) Contamination level, ecological risk, and source identification of heavy metals in the hyporheic zone of the Weihe River, China. Int J Environ Res Public Health 17(3):1070; doi: https://doi.org/10.3390/ijerph 17031070

Publisher's Note Springer Nature remains neutral with regard to jurisdictional claims in published maps and institutional affiliations. 